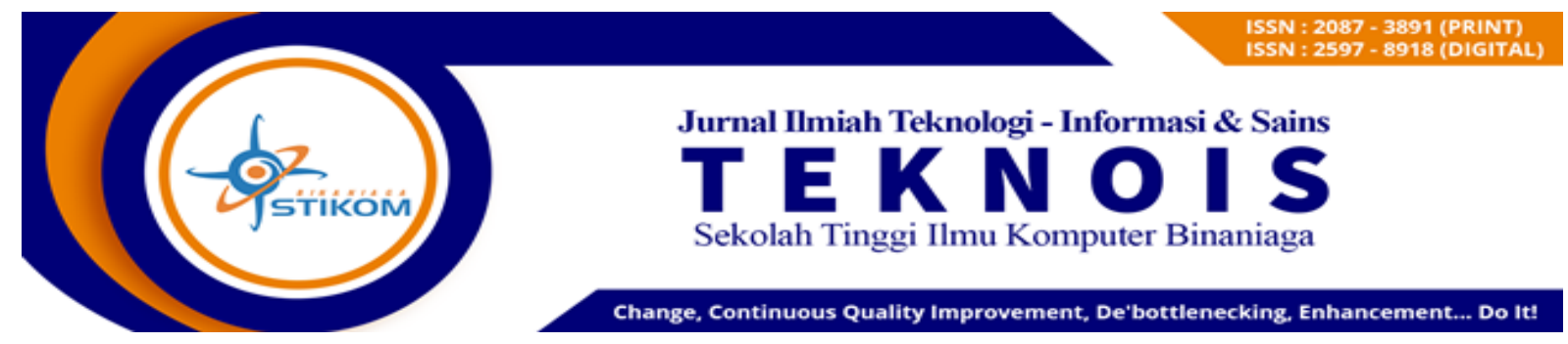

Article DOI : 10.36350/jbs.v11i2.112

Received: September; Accepted : October; Published : November

\title{
Penerapan Metode Weighted Product Dalam Pemantauan Kontaminasi Pada Ruang Kultur Jaringan Kelapa Sawit
}

\author{
Syafrial $^{1 *}$, Aldianto Putra ${ }^{2}$ \\ ${ }^{1}$ Sistem Informasi/Universitas Binaniga Indonesia \\ Email: syafrial@stikombinaniaga.ac.id \\ ${ }^{2}$ Sistem Informasi/ Universitas Binaniga Indonesia \\ Email: aldiantoputra99@gmail.com
}

\begin{abstract}
Palm oil is a product that we usually use every day, even almost every day, companies in producing palm oil increase, so the demand for oil palm seeds increases, resulting in a lot of growing culture space to store oil palm tissue culture, as well as contaminants in the palm oil. The culture room is increasing so that the culture room must be cleaned using special treatment, so from monitoring the contamination in the culture room it must be increased so that the oil palm tissue culture is maintained in its growth, to avoid the decline in seedlings due to contamination, due to the culture room being not sterile, the problem faced by the company, namely the difficulty in determining the most highly contaminated culture room to be cleaned with special treatment. This is because the process of monitoring the culture room has not been computerized. Based on this, we need a method that can monitor to determine the highest contaminated culture room, namely the Weighted Product method. By applying the Weighted Product method, we are able to map something input into to produce output without ignoring the existing factors. The purpose of applying the Weighted Product method is to be able to monitor the oil palm tissue culture room and get the highest contaminated culture space value to make it easier to make decisions. The method used in this study is the Weighted Product method, while the prototyping method is used for system development. The research variables consist of factors that affect the dirtiness of the culture room such as bacteria, fungi, mites, humidity. Based on the results of the feasibility test that has been carried out, it can be obtained that the percentage of system expert eligibility is $93.7 \%$ and is interpreted as very feasible, while for the user eligibility percentage of 100\%, the application made can be categorized into a proper interpretation.
\end{abstract}

Keywords: Culture Room; Contaminations Monitoring; Weighted Product; Variables; feasibility test.

\section{ABSTRAK}

Minyak kelapa sawit merupakan produk yang biasa kita gunakan sehari hari bahkan hampir setiap hari di gunakan, perusahaan dalam memproduksi minyak kelapa sawit meningkat, maka permintaan bibit kelapa sawitpun meningkat sehingga mengakibatkan banyak ruang kultur yang bertambah untuk menyimpan kultur jaringan kelapa sawit, begitu juga kontaminanpada ruang kultur semakin meningkat sehingga ruang kultur harus di bersihkan menggunakan perlakuan khusus, maka dari pemantauan kontaminasi pada ruang kultur harus di tingkatkan agar kultur jaringan kelapa sawit terjaga dalam pertumbuhannya, untuk menghindari terjadinya penurunan bibit akibat kontaminasi, dikarenkan ruang kultur yang tidak seteril, permasalah yang di hadapi oleh persusahaan yaitu kesulitan dalam menentukan ruang kultur yang terkontaminasi paling tinggi untuk di bersihkan dengan perlakuan khusus. Hal ini dikarenakan proses Pemantauan ruang kultur belum terkomputerisasi. Berdasarkan hal tersebut, maka diperlukannya metode yang dapat 
memantau untuk menentukan menentukan ruang kultur yang terkontaminasi paling tinggi yaitu dengan metode Weighted Product. Dengan menerapkannya metode Weighted Product mampu memetakan sesuatu input kedalam untuk menghasilkan ouput tanpa mengabaikan faktor-fator yang ada. Tujuan di terapkannya metode Weighted Product adalah untuk dapat memantau ruang kultur jaringan kelapa sawit dan mendapatkan nilai ruang kultur yang terkontaminasi paling tinggi untuk memudahkan dalam mengambil keputusan. Metode yang digunakan dalam penelitian ini adalah metode Weighted Product, sedangkan untuk pengembangan sistem digunakan adalah metode prototyping. Variabel penelitian yang terdiri dari faktor-faktor yang mempengaruhi kotornya ruang kulturseperti bakteri, fungi, mites, kelembaban. Berdasarkan hasil pengujian kelayakan yang telah dilakukan maka dapat diperoleh hasil presentase kelayakan ahli sistem sebesar 93,7\% dan di interpretasikan sangat layak sedangkan untuk hasil presentase kelayakan pengguna sebesar $100 \%$, maka terkait aplikasi yang di buat dapat di kategorikan ke dalam interpretasi layak.

Keywords: Ruang Kultur; Pemantauan Kontaminasi; Weighted Product; Variabel; Uji Kelayakan.

\section{A. PENDAHULUAN}

\section{Latar Belakang}

Tanaman yang memiliki produk utamanya minyak sawit yang memiliki nilai ekonomis dapat dimanfaatkan di berbagai industri. Mulai dari industri makanan, farmasi sampai industri kosmetik. Bahkan limbahnya pun dapat dimanfaatkan untuk industri mebel, olekimia hingga pakan ternak. Untuk mendapatkan kelapa sawit yang unggul dan berkualitas, bibit kelapa sawit untuk bahan tanam kultur jaringan di ambil pelepah muda agar bisa berkembang biak dan menghasilkan bibit yang masih segar. Kultur jaringan kelapa sawit di produksi setiap minggu sesuai jadwal yang di tentukan untuk mendapatkan kultur yang sempurna karena setiap kultur memiliki kualitas yang berbeda beda.

Kultur jarian yang ada pada Ruang Kultur akan dilakukan pengamatan dan seleksi sampai tahap aklimatisasi sesuai dengan jadwal yang telah ada. Pengamatan yang di lakukan meliputi hasil perkembangan dari kultur jaringan itu sendiri dan mendata kontaminasi yang di dapat dan memisahkan kontaminasi tersebut, Kultur yang terkontaminasi akan di buang karena akan menyebabkan tanaman lainnya ikut terkontaminasi, Sedangkan kultur yang baik dan bagus akan di simpan kembali ke Ruang Kultur untuk di subkultur dan di lakukan pengamatan berikutnya.

Produksi kelapa sawit yang meningkat menyebabkan padatnya kultur kelapa sawit pada Ruang Kultur sehingga pengawasan terhadap Ruang Kultur lebih ditingkatkan agar bibit-bibit kelapa sawit tidak terkontaminasi oleh bakteri, fungi dan mites. Pengawasan pada Ruang Kultur dilakukan dengan pencatatan bibit yang terkontaminasi secara berkala dan langsung memisahkan serta membuang kultur yang terkontaminasi dari bakteri, jamur dan kutu.

Untuk memudahkan pengawasan kontaminasi Ruang Kultur kelapa sawit, penerapan metode Weighted Product diharapkan dapat menjadi solusi yang lebih efektif dan efisien dalam meningkatkan produksi kelapa sawit.

\section{Permasalahan}

Semakin tingginya Jumlah produksi kultur kelapa sawit maka tingkat kontaminasi disetiar Ruang kultur meningkat dari biasanya dan tidak stabil membuat perusahaan membutuhkan analisa prediksi Ruang kultur kelapa sawit yang paling tinggi tingkat kontaminasinya. Berdasarkan fakta tersebut di temukan suatu pemasalahan bagaimana menentukan ruang kultur kelapa sawit yang terkontaminasi paling tinggi. Tidak jarang ruang kultur yang terkontaminasi paling tinggi tidak di lakukan pembersihan lebih lanjut sehingga kontaminasi terus menyebar dan tidak terkontrolnya jumlah kontaminasi.

Karna Ruang kultur tidak di Sterilisasi lebih lanjut berdasarkan kontaminasi tertinggi sehingga ruang kultur dengan tingkat kontaminasi tertinggi akan terus meningkat kontaminasinya dan terus menyebar.

Berdasarkan permasalahan diatas maka dapat diidentifikasikan sebagai berikut : 
Volume 11 Number 2 November 2021 Page. 39-50

Journal Homepage : http://teknois.stikombinaniaga.ac.id/index.php/JBS

DOI Link : http://doi.org/10.36350/jbs.v11i2

a. Belum Efektifnya perangkat aplikasi untuk Pemantauan Kontaminasi pada Ruang kultur

b. Belum Akuratnya penentuan nilai Kontaminasi ruang kultur Jaringan Kelapa sawit

\section{Tujuan}

Adapun tujuan dari penelitian ini adalah :

a. Mendapatkan nilai kontaminasi ruang kulur yang tepat

b. Mendapatkan Proses penentuan yang efektif

c. Mengembangkan Prototype aplikasi pemantauan kontaminasi pada ruang kultur kelapa sawit

d. Mengukur tingkat ketepatan Weighted Product dan efektifitas

\section{Tinjauan Pustaka}

a. Weighted Product

Weighted Product menggunakan teknik perkalian untuk menghubungkan rating atribut, dimana rating tiap atribut harus dipangkatkan terlebih dahulu dengan bobot atribut yang berkaitan.

Langkah-langkah penyelesaian Weighted Product sebagai berikut:

1) Menentukan kriteria-kriteria, yakni kriteria yang akan dijadikan acuan dalam pengambilan keputusan

2) Menentukan rating kecocokan, yakni rating kecocokan setiap alternatif pada setiap kriteria, dan buat matriks keputusan.

3) Melakukan normalisasi bobot.

Bobot Ternormalisasi $=$ Bobot setiap kriterian $/$ penjumlahan semua bobot kriteria. Nilai dari total bobot harus memenuhi persamaan : $\sum_{j=1} w j=1$

4) Menentukan nilai vektor $S$

Dengan cara mengalikan seluruh kriteria bagi sebuah alternatif dengan bobot sebagai pangkat positif untuk kriteria benefit dan bobot berfungsi sebagai pangkat negatif pada kriteria cost.

Rumus untuk menghitung nilai preferensi untuk alternatif $\mathrm{Ai}$, diberikan sebagai berikut : $S i=\prod_{j=1}^{n} X_{i j} W j, i=1,2, \ldots, m$

5) Menentukan nilai vektor $V$, nilai preferensi relatif dari setiap alternatif dapat dihitung dengan rumus :

$\mathrm{Vi}=\frac{\prod_{j}^{n}=1 X_{i j} W_{j}}{\prod_{j}^{n}=1\left(X_{j}\right)^{W j}} \quad,=1,2, \ldots, m$

6) Merangking Nilai Vektor V, merupakan kesimpulan sebagai tahap akhir.

\section{B. METODE}

\section{Prosedur Pengembangan}

Proses pengembangan atau prosedur pengembangan merupakan langkah-langkah yang dilakukan dalam proses pembangunan.

Proses pengembangan merupakan langkah-langkah yang dilakukan dalam proses pembangunan. Gambar tersebut menggambarkan proses penelitian dan pengembangan yang akan dilakukan. Dapat dijelaskan prosedur pengembangan dari penelitian ini sebagaimana yang ditunjukkan oleh gambar.
a. Analisa Data
Dimana pada proses pengembangan tahap ini, terdapat proses observasi objek yang akan diteliti, identifikasi masalah, penentuan metode dan pengumpulan data.
b. Desain Aplikasi
Desain aplikasi merupakan perosedur pengembangan untuk mendesain aplikasi yang akan dikembangkan seperti desain input, proses dan juga output yang akan dihasilkan oleh sistem sesuai kebutuhan.
c. Pembangunan Aplikasi 
Volume 11 Number 2 November 2021 Page. 39-50

Journal Homepage : http://teknois.stikombinaniaga.ac.id/index.php/JBS

DOI Link : http://doi.org/10.36350/jbs.v11i2

Mengaplikasikan metode yang digunakan yaitu WP kedalam bahasa pemrograman sehingga desain aplikasi bisa menjadi sebuah program

d. Uji Coba

Yaitu melakukan uji coba terhadap sistem untuk mengetahui kesesuaian sistem dengan kebutuhan dan kesalahan yang ditemukan dalam system untuk uji coba terdiri dari uji pengguna dan uji ahli

e. Revisi produk

Yaitu melakukan perbaikan dan mengevaluasi sistem sudah baik atau belum, Seandainya sudah baik, makan akan dilanjukan ke implementasi, tetapi apabila saat di ujicoba ada permasalahan maka akan proses akan kembali ke tahap pembangunan aplikasi.

f. Implementasi

Merupakan suatu kebutuhan dalam sistem yang telah selesai dan sesuai sehingga dapat di terapkan pada sistem

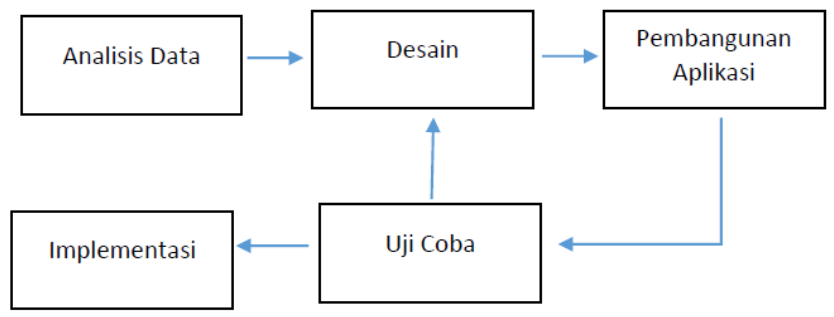

Gambar 1. Prosedur Pengembangan

\section{Desain Ujicoba}

Dalam penelitian Pemantauan Ruang kultur jaringan kelapa sawit ada 2 pengujian, adapun tahap tersebut adalah

a. Uji Coba Ahli

Pengujian ini dilakukan oleh 2 orang ahli yang memiliki keahlian di bidangnya, termasuk menguji ketepatan sistem untuk menentukan ruang kultur yang terkontaminasi.

b. Uji Coba Pengguna

Pengujian kepada pengguna dilakukan untuk mengetahui kebergunaan dari produk yang dihasilkan. Uji coba akan dilakukan dengan menyebarkan kuesioner kepada pengguna 1 mandor dan 1 PIC

\section{Instrumen Penelitian}

a. Instrumen Untuk Ahli

Tabel 1. Instrumen Untuk Ahli

\begin{tabular}{|c|c|c|c|c|c|}
\hline \multirow{2}{*}{ No } & \multirow{2}{*}{$\begin{array}{l}\text { Proses yang } \\
\text { diuji }\end{array}$} & \multirow{2}{*}{$\begin{array}{l}\text { Skenario } \\
\text { Pengujian }\end{array}$} & \multirow{2}{*}{$\begin{array}{l}\text { Hasil yang } \\
\text { diharapkan }\end{array}$} & \multicolumn{2}{|c|}{ Hasil Pengujian } \\
\hline & & & & YA & TIDAK \\
\hline 1 & $\begin{array}{l}\text { Proses input } \\
\text { kriteria }\end{array}$ & $\begin{array}{l}\text { Melakukan } \\
\text { input kriteria } \\
\text { dengan } \\
\text { mengetikkan } \\
\text { kriteria nya } \\
\text { pada kolom } \\
\text { yang sudah di } \\
\text { sediakan }\end{array}$ & $\begin{array}{l}\text { Kemudahan } \\
\text { user dalam } \\
\text { menginputkan } \\
\text { kriteria } \\
\text { berdasarkan } \\
\text { kebutuhannya }\end{array}$ & & \\
\hline 2 & $\begin{array}{l}\text { Proses input } \\
\text { alternatif }\end{array}$ & $\begin{array}{l}\text { Melakukan } \\
\text { input alternatif } \\
\text { dengan } \\
\text { mengetikkan } \\
\text { nama } \\
\text { alternatifnya }\end{array}$ & $\begin{array}{l}\text { Kemudahan } \\
\text { user dalam } \\
\text { menginputkan } \\
\text { Ruang Kultur } \\
\text { sebagai } \\
\text { alternatif }\end{array}$ & & \\
\hline 4 & $\begin{array}{l}\text { Proses input } \\
\text { nilai } \\
\text { alternatif } \\
\text { terhadap }\end{array}$ & $\begin{array}{l}\text { Melakukan } \\
\text { input nilai } \\
\text { alternatif } \\
\text { terhadap }\end{array}$ & $\begin{array}{l}\text { Kemudahan } \\
\text { user dalam } \\
\text { menginputkan } \\
\text { nilai alternatif }\end{array}$ & & \\
\hline
\end{tabular}


Volume 11 Number 2 November 2021 Page. 39-50

Journal Homepage : http://teknois.stikombinaniaga.ac.id/index.php/JBS

DOI Link : http://doi.org/10.36350/jbs.v11i2

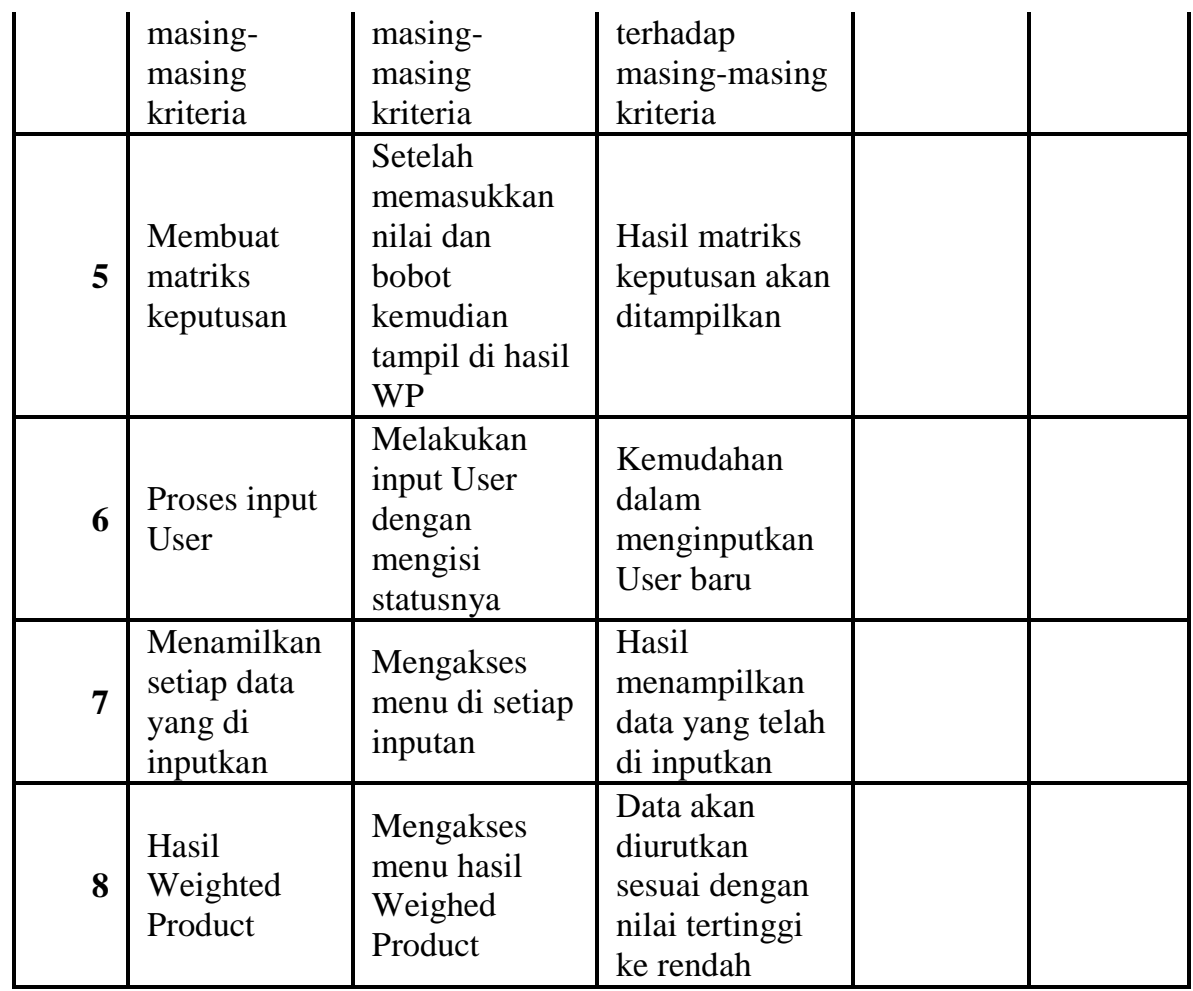

\section{b. Instrumen Untuk Pengguna}

Tabel 2. Instrumen Untuk Pengguna

\begin{tabular}{|c|c|c|c|c|c|c|c|}
\hline \multirow[t]{2}{*}{ No } & \multirow[t]{2}{*}{ Pernyataan } & \multicolumn{6}{|c|}{ Tidak setuju / Setuju } \\
\hline & & 1 & 2 & 3 & 4 & 5 & NA \\
\hline 1 & $\begin{array}{l}\text { Secara keseluruhan, saya puas dengan kemudahan } \\
\text { penggunaan aplikasi ini }\end{array}$ & & & & & & \\
\hline 2 & Aplikasi mudah digunakana & & & & & & \\
\hline 3 & $\begin{array}{l}\text { Saya secara efektif dapat menyelesaikan tugas-tugas dan } \\
\text { scenario menggunakan aplikasi ini }\end{array}$ & & & & & & \\
\hline 4 & $\begin{array}{l}\text { Saya bisa menyelesaikan tugas-tugas dan scenario } \\
\text { menggunakan aplikasi ini }\end{array}$ & & & & & & \\
\hline 5 & $\begin{array}{l}\text { Saya dengan efisien dapat menyelesaikan tugas-tugas dan } \\
\text { scenario menggunakan aplikasi ini }\end{array}$ & & & & & & \\
\hline 6 & Saya merasa nyaman menggunakan aplikasi ini & & & & & & \\
\hline 7 & Mudah untuk belajar menggunakan aplikasi ini & & & & & & \\
\hline 8 & $\begin{array}{l}\text { Saya percaya saya bisa menjadi produktif dengan cepat } \\
\text { menggunakan aplikasi ini }\end{array}$ & & & & & & \\
\hline 9 & $\begin{array}{l}\text { Aplikasi ini memberikan pesan kesalahan yang jelas } \\
\text { memberitahu saya bagaimana untuk memperbaiki } \\
\text { masalah }\end{array}$ & & & & & & \\
\hline 10 & $\begin{array}{l}\text { Setiap kali saya melakukan kesalahan dengan } \\
\text { menggunakan aplikasi, saya bisa pulih dengan mudah dan } \\
\text { cepat }\end{array}$ & & & & & & \\
\hline 11 & $\begin{array}{l}\text { Informasi (seperti online pesan bantuan pada layer, dan } \\
\text { dokumentasi lainnya) disediakan dengan jelas oleh } \\
\text { aplikasi ini }\end{array}$ & & & & & & \\
\hline 12 & Mudah untuk menemukan informasi yang saya butuhkan & & & & & & \\
\hline 13 & Informasi yang disediakan aplikasi ini mudah dimengerti & & & & & & \\
\hline 14 & $\begin{array}{l}\text { Informasi efektif dalam membantu menyelesaikan tugas- } \\
\text { tugas dan scenario }\end{array}$ & & & & & & \\
\hline 15 & Organisasi informasi pada layer aplikasi jelas & & & & & & \\
\hline 16 & Antarmuka aplikasi ini menyenangkan & & & & & & \\
\hline 17 & Saya suka menggunakan antarmuka aplikasi ini & & & & & & \\
\hline
\end{tabular}


Volume 11 Number 2 November 2021 Page. 39-50

Journal Homepage : $\underline{\text { http://teknois.stikombinaniaga.ac.id/index.php/JBS }}$

DOI Link : http://doi.org/10.36350/jbs.v11i2

\begin{tabular}{|l|l|l|l|l|l|l|l|}
\hline 18 & $\begin{array}{l}\text { Aplikasi ini memiliki semua fungsi dan kemampuan yang } \\
\text { saya harapkan }\end{array}$ & & & & & & \\
\hline 19 & Secara keseluruhan, saya puas dengan aplikasi ini. & & & & & & \\
\hline
\end{tabular}

\section{Teknik Analisa Data}

\section{a. Uji Produk}

Dalam penelitian ini, metode analisis data dengan menggunakan presentase kelayakan.

Adapun rumus yang digunakan adalah sebagai berikut:

$$
\text { Presentasi kelayakan }(\%)=\frac{\text { skoryang diobservasi }}{\text { skoryang diharapkan }} \times 100 \%
$$

Hasil persentase digunakan untuk memberikan jawaban atas kelayakan aspek yang diteliti. Menurut Arikunto (2009, p.44), kualifikasi dibagi menjadi lima kategori. Rasio ini memperhitungkan kisaran persentase. Nilai harapan tertinggi adalah $100 \%$, dan nilai minimum adalah 0\%. Tabel 3 mencantumkan ruang lingkup kategori kualifikasi menurut Arikunto (2009, p.44).

Tabel 3 Kategori Kelayakan Menurut Arikunto

\begin{tabular}{|c|c|}
\hline Persentase Pencapaian & Interpretasi \\
\hline$<21 \%$ & Sangat Tidak Layak \\
\hline $21 \%-40 \%$ & Tidak Layak \\
\hline $41 \%-60 \%$ & Cukup Layak \\
\hline $61 \%-80 \%$ & Layak \\
\hline $81 \%-100 \%$ & Sangat Layak \\
\hline
\end{tabular}

(Sumber : Arikunto, 2009, p.44)

Untuk mengetahui kelayakan digunakan tabel diatas sebagai acuan penilaian data yang dihasilkan dari validasi pengguna.

\section{b. Uji Hasil}

Rank spearman adalah salah satu ukuran deskriptif untuk mengukur tingkat korelassi (interdependency) dua variabel, dengan syarat kedua variabel minimal mencapai pengukuran ordinal (berbentuk rangking). Uji korelasi ini digunakan untuk menguji hipotesis asosiatif dua variabel bila datanya berskala ordinal (ranking). Uji kolerasi rank spearman menggunakan rumus yang bersumber dari (sugiyono,2012) sebagai berikut :

$$
\rho=1-\frac{6 \sum d_{i}^{2}}{n\left(n^{2}-1\right)}
$$

Keterangan :

$\rho=$ Koefisien korelasi Rank Spearman

$\mathrm{d}=$ Rangking Data Variabel $\mathrm{X}_{\mathrm{i}}-\mathrm{Y}_{\mathrm{i}}$

$\mathrm{n}=$ Jumlah Responden

Korelasi adalah adalah salah satu teknik statistik yang digunakan untuk mengetahui keeratan hubungan antara dua variabel dan untuk mengetahui arah hubungan yang terjadi. Uji signifikansi rank spearman ditunjukkan melalui variabel yang ditujukan pada nilai korelasi perhatikan pada tabel 4 dibawah :

Tabel 4. Rank Spearman

\begin{tabular}{|c|c|}
\hline No & Tingkat Hubungan \\
\hline $0,00-0,19$ & Sangat Rendah \\
\hline $0,20-0,39$ & Rendah \\
\hline $0,40-0,59$ & Sedang \\
\hline $0,60-0,79$ & Kuat \\
\hline $0,80-1,00$ & Sangat Kuat \\
\hline
\end{tabular}

\section{HASIL DAN PEMBAHASAN}

\section{Hasil}
a. Analisa Produk 
Volume 11 Number 2 November 2021 Page. 39-50 Journal Homepage : http://teknois.stikombinaniaga.ac.id/index.php/JBS

DOI Link : http://doi.org/10.36350/jbs.v11i2

\section{1) Usecase Diagram}

Berdasarkan analisas dan perhitungan tersebut diatas, dikembangkan sistem informasi untuk pengawasan Ruang Kultur dijelaskan pada gambar diagram use case berikut ini.

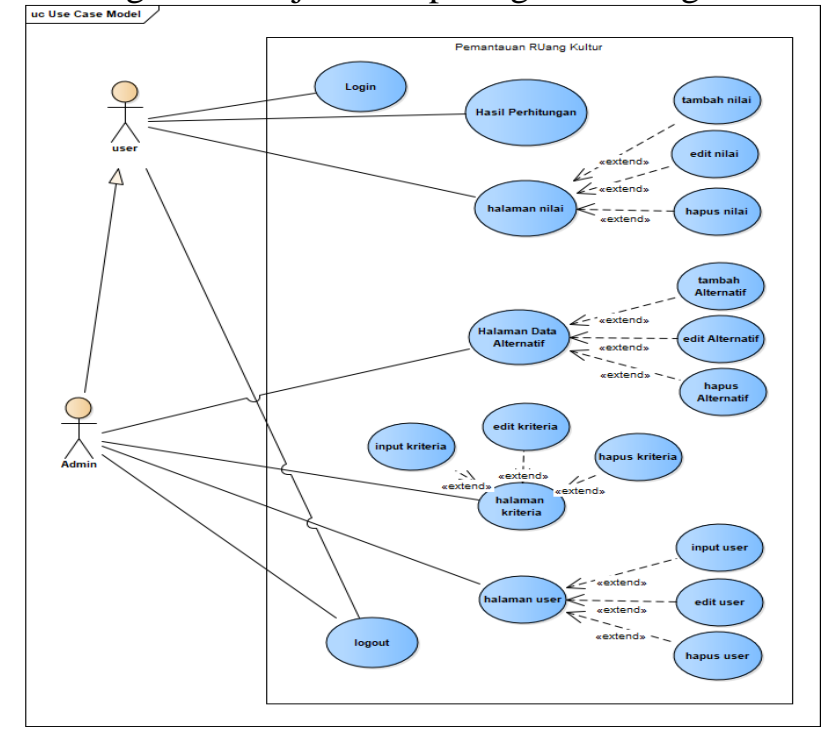

Gambar 2. Usecase Diagram

Pada gambar 2 dapat terlihat kegiatan apa saja yang bisa dilakukan oleh aktor yang terlibat dalam sistem. Disini terdapat 2 aktor yaitu user dan admin. Admin bisa melakukan semua kegiatan namun untuk user dibatasi pada kegiatan kelola user karena untuk kelola user hanya bisa dilakukan oleh admin.

2) Interface

a) Form Input Kriteria

Pada halaman ini Administrator dapat memasukan kriteria seusi kebutuhan yang akan menjadi penilaian pada Ruang Kultur yang telah terdaftar di pusat data.

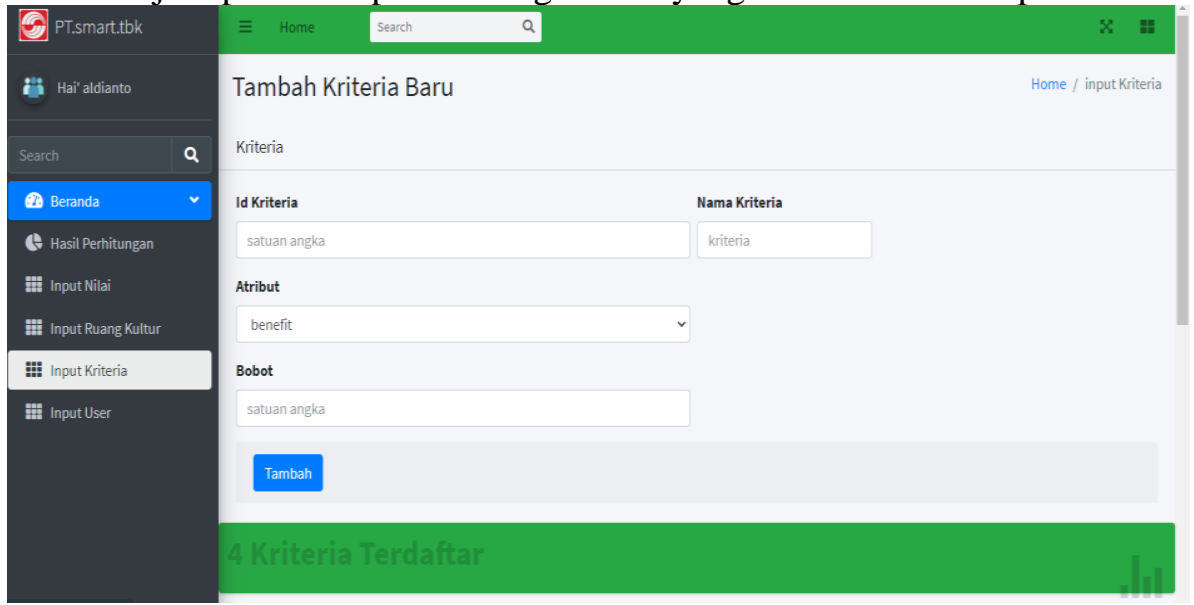

Gambar 3. Form Input Kriteria

b) Form Input Nilai

Pada halaman Ini Administrator dan user dapat memasukan nilai kriteria di setiap Ruang Kultur yang sudah terdaftar, nilai tersebut harus terisi minimal dengan nilai 1 (satu). 
Volume 11 Number 2 November 2021 Page. 39-50

Journal Homepage : $\underline{\text { http://teknois.stikombinaniaga.ac.id/index.php/JBS }}$

DOI Link : http://doi.org/10.36350/jbs.v11i2

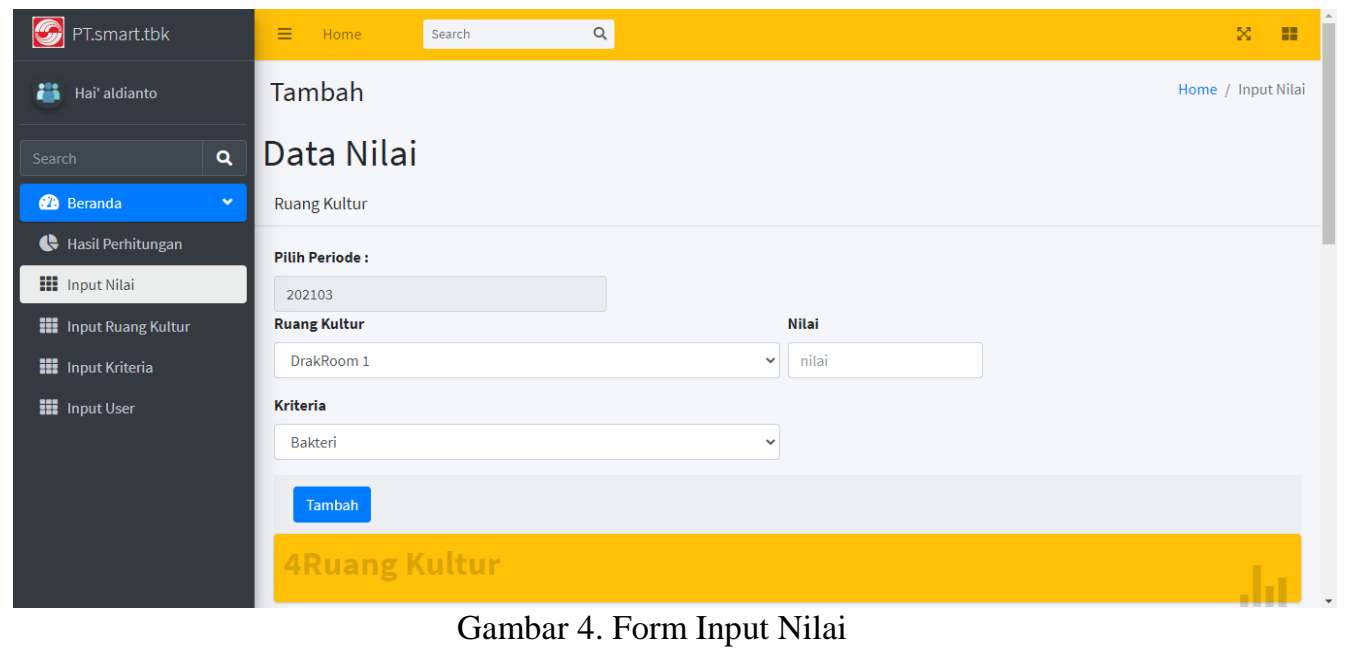

c) Form Hasil Hitungan

Pada halaman ini data nilai yang telah dimasukan akan dihitung menggunakan metode Weighted Product. Nilai hasil perhitungan akan di tampilkan di halaman ini serta mengurutkan atau merangking Ruang Kultur yang paling terkontaminasi.

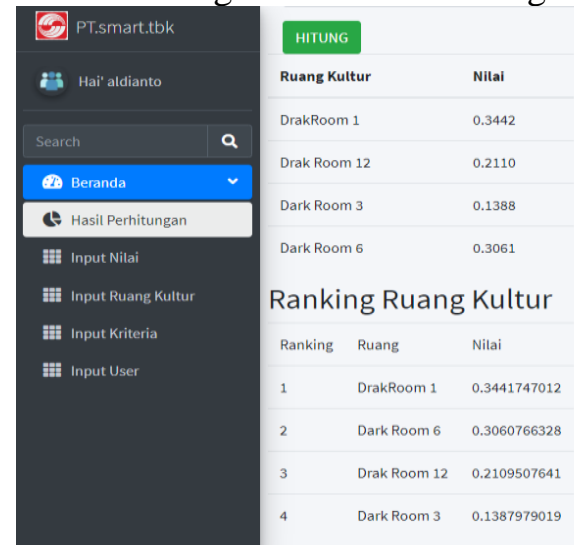

\section{b. Analisa Metode}

Gambar 5. Form Hasil

Analisa dan perhitungan yang dilakukan sesuai dengan langkah-langkah pada metode Weighted Product hingga diperoleh hasil yang didapat dilihat pada tabel-tabel dibawah ini :

Tabel 5. Parameter ukur nilai berdasarkan Kriteria

\begin{tabular}{|l|l|l|}
\hline Nilai & Kriteria & Bobot \\
\hline Jumlah Bakteri $>0$ & Bakteri & 3 \\
\hline Jumlah Fungi $>0$ & Fungi & 4 \\
\hline Jumlah Mites $>0$ & Mites & 5 \\
\hline Kelembaban Ruang Kultur $>0$ & Kelembaban & 2 \\
\hline
\end{tabular}

Tabel 6. bobot (W) setiap kriteria

\begin{tabular}{|l|l|l|}
\hline Kriteria & Simbol & Bobot \\
\hline Bakteri & $\mathrm{C}_{1}$ & 3 \\
\hline Fungi & $\mathrm{C}_{2}$ & 4 \\
\hline Mites & $\mathrm{C}_{3}$ & 5 \\
\hline Kelembaban & $\mathrm{C}_{4}$ & 2 \\
\hline
\end{tabular}

Tabel 7. Penilaian

\begin{tabular}{|l|l|l|l|l|}
\hline Alternatif & $\mathrm{C}_{1}$ & $\mathrm{C}_{2}$ & $\mathrm{C}_{3}$ & $\mathrm{C}_{4}$ \\
\hline Dark Room 1 & 743 & 2867 & 1 & 70 \\
\hline Dark Room 2 & 621 & 667 & 1 & 55 \\
\hline
\end{tabular}


Volume 11 Number 2 November 2021 Page. 39-50

Journal Homepage : http://teknois.stikombinaniaga.ac.id/index.php/JBS

DOI Link : http://doi.org/10.36350/jbs.v11i2

\begin{tabular}{|l|l|l|l|l|}
\hline Dark Room 3 & 3025 & 45 & 1 & 60 \\
\hline Dark Room 4 & 854 & 1738 & 1 & 68 \\
\hline
\end{tabular}

Tabel 8. Normalisasi bobot mencari W

\begin{tabular}{|l|l|}
\hline Kriteria & WJ \\
\hline Bakteri $\left(\mathrm{C}_{1}\right)$ & 0,21 \\
\hline Fungi $\left(\mathrm{C}_{2}\right)$ & 0,29 \\
\hline Mites $\left(\mathrm{C}_{3}\right)$ & 0,36 \\
\hline Kelembaban $\left(\mathrm{C}_{4}\right)$ & 0,14 \\
\hline
\end{tabular}

Tabel 9. Keputusan bobot ternormalisasi

\begin{tabular}{|l|l|l|l|l|}
\hline Alternatif & $\mathrm{C}_{1}$ & $\mathrm{C}_{2}$ & $\mathrm{C}_{3}$ & $\mathrm{C}_{4}$ \\
\hline Dark Room 1 & 4,12 & 9,72 & 1,00 & 1,83 \\
\hline Dark Room 2 & 3,97 & 6,41 & 1,00 & 1,77 \\
\hline Dark Room 3 & 5,57 & 2,97 & 1,00 & 1,79 \\
\hline Dark Room 4 & 4,25 & 8,43 & 1,00 & 1,83 \\
\hline
\end{tabular}

Tabel 10. Nilai S ideal Positif dan ideal negative

\begin{tabular}{|l|l|l|}
\hline Nilai & S+ & S- \\
\hline S1 & 73,55865957 & 0,013760617 \\
\hline S2 & 45,08540397 & 0,022435539 \\
\hline S3 & 29,66454994 & 0,034106933 \\
\hline S4 & 65,41615858 & 0,015472151 \\
\hline
\end{tabular}

Tabel 11. Menentukan Nilai V

\begin{tabular}{|l|l|}
\hline Nilai & V \\
\hline V1 & 0,3442 \\
\hline V2 & 0,2110 \\
\hline V3 & 0,1388 \\
\hline V4 & 0,3061 \\
\hline
\end{tabular}

Tabel 12. Hasil Perankingan

\begin{tabular}{|l|l|l|}
\hline Alternatif & V & Rank \\
\hline Dark Room 1 & 0,344174701 & 1 \\
\hline Dark Room 4 & 0,306076633 & 2 \\
\hline Dark Room 2 & 0,210950764 & 3 \\
\hline Dark Room 3 & 0,138797902 & 4 \\
\hline
\end{tabular}

Dengan melihat hasil dari tabel diatas maka dapat disimpulkan bahwa Ruang Kultur 1 atau Dark Room 1 memiliki peringkat 1 dalam ruangan terkontaminasi dengan total nilai 0,3442, diikuti oleh Dark Room 6 diperingkat 2 dengan total nilai 0,3061, di ruang ke 3 Dark Room 12 dengan total nilai 0,2110, di Ruang ke 4 Dark Room 3 dengan total nilai 0,1338 .

\section{Pembahasan}

a. Hasil Uji Coba Ahli

Tabel 13. Rekapitulasi Kuesioner Ahli

\begin{tabular}{|c|l|l|l|c|c|}
\hline No & $\begin{array}{l}\text { Proses yang } \\
\text { diuji }\end{array}$ & Skenario Pengujian & $\begin{array}{l}\text { Hasil yang } \\
\text { diharapkan }\end{array}$ & \multicolumn{2}{|c|}{$\begin{array}{c}\text { Hasil } \\
\text { Pengujian }\end{array}$} \\
\cline { 4 - 6 } & & $\begin{array}{l}\text { R1 } \\
\text { Melakukan input } \\
\text { kriteria dengan } \\
\text { mengetikkan kriteria } \\
\text { nya pada kolom yang } \\
\text { sudah di sediakan }\end{array}$ & $\begin{array}{l}\text { Kemudahan user } \\
\text { dalam } \\
\text { menginputkan } \\
\text { kriteria } \\
\text { kerdasarkan } \\
\text { kebutuhannya }\end{array}$ & $\mathbf{1}$ & $\mathbf{1}$ \\
\hline $\mathbf{2}$ & Proses input & Melakukan input & Kemudahan user & $\mathbf{1}$ & $\mathbf{1}$ \\
\hline
\end{tabular}


Volume 11 Number 2 November 2021 Page. 39-50

Journal Homepage : $\underline{\text { http://teknois.stikombinaniaga.ac.id/index.php/JBS }}$

DOI Link : http://doi.org/10.36350/ibs.v11i2

\begin{tabular}{|c|c|c|c|c|c|}
\hline & alternatif & $\begin{array}{l}\text { alternatif dengan } \\
\text { mengetikkan nama } \\
\text { alternatifnya }\end{array}$ & $\begin{array}{l}\text { dalam } \\
\text { menginputkan } \\
\text { Ruang Kultur } \\
\text { sebagai alternatif }\end{array}$ & & \\
\hline 4 & $\begin{array}{l}\text { Proses input } \\
\text { nilai } \\
\text { alternatif } \\
\text { terhadap } \\
\text { masing- } \\
\text { masing } \\
\text { kriteria }\end{array}$ & $\begin{array}{l}\text { Melakukan input } \\
\text { nilai alternatif } \\
\text { terhadap masing- } \\
\text { masing kriteria }\end{array}$ & $\begin{array}{l}\text { Kemudahan user } \\
\text { dalam } \\
\text { menginputkan } \\
\text { nilai alternatif } \\
\text { terhadap masing- } \\
\text { masing kriteria }\end{array}$ & 1 & 1 \\
\hline 5 & $\begin{array}{l}\text { Membuat } \\
\text { matriks } \\
\text { keputusan }\end{array}$ & $\begin{array}{l}\text { Setelah memasukkan } \\
\text { nilai dan bobot } \\
\text { kemudian tampil di } \\
\text { hasil WP }\end{array}$ & $\begin{array}{l}\text { Hasil matriks } \\
\text { keputusan akan } \\
\text { ditampilkan }\end{array}$ & 1 & $\mathbf{0}$ \\
\hline 6 & $\begin{array}{l}\text { Proses input } \\
\text { User }\end{array}$ & $\begin{array}{l}\text { Melakukan input } \\
\text { User dengan mengisi } \\
\text { statusnya }\end{array}$ & $\begin{array}{l}\text { Kemudahan } \\
\text { dalam } \\
\text { menginputkan } \\
\text { User baru }\end{array}$ & 1 & 1 \\
\hline 7 & $\begin{array}{l}\text { Menamilkan } \\
\text { setiap data } \\
\text { yang di } \\
\text { inputkan }\end{array}$ & $\begin{array}{l}\text { Mengakses menu di } \\
\text { setiap inputan }\end{array}$ & $\begin{array}{l}\text { Hasil } \\
\text { menampilkan data } \\
\text { yang telah di } \\
\text { inputkan }\end{array}$ & 1 & 1 \\
\hline 8 & $\begin{array}{l}\text { Hasil } \\
\text { Weighted } \\
\text { Product }\end{array}$ & $\begin{array}{l}\text { Mengakses menu } \\
\text { hasil Weighed } \\
\text { Product }\end{array}$ & $\begin{array}{l}\text { Data akan } \\
\text { diurutkan sesuai } \\
\text { dengan nilai } \\
\text { tertinggi ke } \\
\text { rendah }\end{array}$ & 1 & 1 \\
\hline
\end{tabular}

$$
\begin{aligned}
& \text { Persentase Kelayakan } \%=\frac{(8+7)}{(8+8)} * 100 \% \\
& \text { Persentase Kelayakan } \%=\frac{15}{16} * 100 \%=93,7 \%
\end{aligned}
$$

Dari hasil perhitungan kelayakan tersebut, maka dapat dikatakan bahwa sistem sangat layak dikembangkan. Dengan skala kelayakan bisa dilihat di tabel 4.12 tabel kategori kelayakan.

b. Hasil Kuesioner Pengguna

Tabel 14. Rekapitulasi Kuesioner Pengguna

\begin{tabular}{|r|l|l|l|}
\hline \multirow{2}{*}{ No } & \multirow{2}{*}{ Pernyataan } & \multicolumn{2}{|c|}{ Responden } \\
\cline { 3 - 4 } & & & 1 \\
\hline 1 & System Use 1 & 5 & 5 \\
\hline 2 & System Use 2 & 5 & 5 \\
\hline 3 & System Use 3 & 5 & 5 \\
\hline 4 & System Use 4 & 5 & 5 \\
\hline 5 & System Use 5 & 5 & 5 \\
\hline 6 & System Use 6 & 5 & 5 \\
\hline 7 & System Use 7 & 5 & 5 \\
\hline 8 & System Use 8 & 5 & 5 \\
\hline 9 & Information Quality 1 & 5 & 5 \\
\hline 10 & Information Quality 2 & 5 & 5 \\
\hline 11 & Information Quality 3 & 5 & 5 \\
\hline 12 & Information Quality 4 & 5 & 5 \\
\hline 13 & Information Quality 5 & 5 & 5 \\
\hline 14 & Information Quality 6 & 5 & 5 \\
\hline 15 & Information Quality 7 & 5 & 5 \\
\hline 16 & Interface Quality 1 & 5 & 5 \\
\hline
\end{tabular}


Volume 11 Number 2 November 2021 Page. 39-50

Journal Homepage : http://teknois.stikombinaniaga.ac.id/index.php/JBS

DOI Link : http://doi.org/10.36350/jbs.v11i2

\begin{tabular}{|l|l|l|l|}
17 & Interface Quality 2 & 5 & 5 \\
\hline 18 & Interface Quality 3 & 5 & 5 \\
\hline 19 & Interface Quality 4 & 5 & 5 \\
\hline
\end{tabular}

\section{Overall}

Presentase kelayakan $(\%)=\frac{\text { Skoryang diobservasi }}{\text { Skoryang diharapkan }} \times 100 \%$

Presentase kelayakan $(\%)=\frac{95+95}{95+95} \times 100 \%$

Presentase kelayakan $(\%)=\frac{190}{190} \times 100 \%$

Presentase kelayakan $(\%)=100 \%$

\section{System Use}

Presentase kelayakan $(\%)=\frac{\text { skoryang diobservasi }}{\text { skoryang diharapkan }} \times 100 \%$

Presentase kelayakan $(\%)=\frac{40+40}{40+40} \times 100 \%$

Presentase kelayakan $(\%)=\frac{80}{80} \times 100 \%$

Presentase kelayakan $(\%)=100 \%$

\section{Informaton Quality}

Presentase kelayakan $(\%)=\frac{\text { skoryang diobservasi }}{\text { skoryang diharapkan }} \times 100 \%$

Presentase kelayakan $(\%)=\frac{35+35}{35+35} \times 100 \%$

Presentase kelayakan $(\%)=\frac{70}{70} \times 100 \%$

Presentase kelayakan $(\%)=100 \%$

\section{Interface Quality}

Presentase kelayakan $(\%)=\frac{\text { Skoryang diobservasi }}{\text { Skoryang diharapkan }} \times 100 \%$

Presentase kelayakan $(\%)=\frac{20+20}{20+20} \times 100 \%$

Presentase kelayakan $(\%)=\frac{40}{40} \times 100 \%$

Presentase kelayakan $(\%)=100 \%$

Dari hasil perhitungan nilai Overall, System Use, Information Quality, Interface Quality di atas maka didapatkan kesimpulan sistem layak untuk digunakan

c. Uji Hasil

jumlah dari perhitungan ranking sebelum dan setelah menggunakan sistem adalah seperti demikian. Dilanjutkan dengan menghitung menggunakan rumus korelasi Rank Spearman adalah sebagai berikut :

$$
\begin{gathered}
\rho=1-\frac{6 \sum d_{i}^{2}}{n\left(n^{2}-1\right)} \\
\rho=1-\frac{6 \times 6}{4\left(4^{2}-1\right)} \\
\rho=1-\frac{36}{192} \\
\rho=1-0,1875 \\
\rho=0,8125
\end{gathered}
$$

Hasil perhitungan menghasilkan nilai koefisien sebesar 0,81 yang berarti tingkat hubungan dari dua variabel memiliki nilai sedang atau mendekati normal.

\section{KESIMPULAN}

Berdasarkan hasil penelitian yang dilakukan, kesimpulan yang bisa diuraikan antara lain: 
1. Dapat memberikan Hasil ruang kultur yang terkontaminasi berdasarkan hasil Perhitungan dengan variabel menggunakan Metode Weighted Product.

2. Dengan menerapkan metode Weighted Product dalam Pemantauan kontaminasi ruang kultur jaringan dapat membantu pengguna dalam menentukan ruang kultur yang terkontaminasi paling tinggi setiap bulannya.

3. Telah dilakukan uji kelayakan atau kebergunaan terhadap prototipe yang dikembangkan dengan nilai presentase kelayakan yang didapat berdasarkan kuesioner yang disebarkan pada pengguna sebesar $100 \%$ yang bermakna sistem masuk ke dalam kategori "Sangat Layak" digunakan.Sedangkan hasil penyebaran pada ahli menunjukan angka kelayakan sebesar $93,7 \%$.

\section{E. DAFTAR PUSTAKA}

[1] Abbas, I. (2016). Penerapan Metode Weighted Product (WP) Berbasis Sistem Pengambilan Keputusan Untuk Pemberian Dana Bantuan Mandiridesa Wisata Pada Dinas Perhubungan Pariwisata Kabupaten Bone Bolango

[2] Baba, B. (2017). Metode Weightd Product (Wp ) Dalam Sistem Pendukung Keputusan. January.

[3] Hidayat, C. R., Mufizar, T., \& Ramdani, M. D. (2018). Implementasi Metode Weighted Product Pada Sistem Pendukung Keputusan Seleksi Calon Karyawan Bpjs Kesehatan Tasikmalaya

[4] Jalil, Abdul; Ningrum, Ika; Muchtar, M. (2017). Spk pemberian kredit menggunakan metode. SemanTIK, 3(1), 173-180.

[5] Khairina, D. M., Ivando, D., \& Maharani, S. (2016). Implementasi Metode Weighted Product Untuk Aplikasi Pemilihan Smartphone Android. JURNAL INFOTEL - Informatika Telekomunikasi Elektronika, 8(1), 16. https://doi.org/10.20895/infotel.v8i1.47

[6] Kharisma Wahyudin, \& Masniah. (2017). Penerapan Metode Weighted Product Untuk Penilaian Eco Office Award Pada Dinas Lingkungan Hidup Kabupaten - Kota. 6(3), 1655-1666

[7] Kusumadewi, S. H. (2006). Fuzzy Multi-Attribute Decision Making (Fuzzy MADM). Graha Ilmu Yogyakarta.

[8] Manik, A. R. S., Nurhadiyono, B., \& Rahayu, Y. (2015). Implementasi Metode Weighted Product (Wp) Dalam Sistem Pendukung Keputusan Untuk Menyeleksi Penerima Beras Masyarakat Miskin ( Raskin ). Techno.COM, 14(2), 109-114

[9] Prasetyo, A. B. (2017). Weighted Product (Wp) Untuk Membangun Mesin Pencari Data Lulusan Perguruan Tinggi Berdasarkan Kebutuhan Pengguna Lulusan. Simetris: Jurnal Teknik Mesin, Elektro Dan Ilmu Komputer, 8(1), 155-168. https://doi.org/10.24176/simet.v8i1.849

[10] Supriyono, H. (2015). Pemilihan Rumah Tinggal Menggunakan Metode Weighted Product. Khazanah Informatika: Jurnal Ilmu Komputer Dan Informatika, 1(1), 23. https://doi.org/10.23917/khif.v1i1.1178

[11] Wedhasmara, A., \& Efendi, R. (2016). Implementasi Metode Weighted Product Dalam Sistem Pendukung Keputusan Pemilihan Lokasi Tempat Pembuangan Akhir. Jurnal Sistem Informasi (JSI), 8(1), 2355-4614. http://ejournal.unsri.ac.id/index.php/jsi/index

[12] Warmansyah, J. (2020). Metode Penelitian \& Pengolahan Data Untuk Pengambilan Keputusan Pada Perusahaan. Deepublish Publisher 